\title{
African National Congress drafts blueprint for South African science
}

Cape Town. The African National Congress (ANC) has released its new science and technology policy, a document aimed at reversing what the organization claims is the apartheid era's legacy of directing "the benefits of technology...to the white minority at the expense of the majority." Because the ANC is considered likely to emerge as South Africa's new government, this plan may well direct the nation's science and technology policy over the next decade.

The new policy focuses on education as the essential ingredient to the growth and development of a scientifically literate and technically able society. It promises highquality programmes in science, mathematics and technical education at secondary and higher levels, including worker training and education, for South Africans of all races. There are almost no qualified science or technical teachers in black schools because of a shortage of qualified instructors.

It is not quite clear, however, how the ANC expects to recruit enough mathematics and science teachers to reach its goal. In 1989 (the last year for which figures are available) the country's 22 universities produced only 92 physics, 171 chemistry and 216 mathematics majors between them.

The policy supports the growth of indig- enous technologies, especially by encouraging increased spending on research and development by the private sector, but does not provide details on how to achieve this aim. The ANC states that its policy objectives "do not require additional state funds to be directed towards [science and technology] in the short-term, since they can be achieved through a more efficient and equitable use of the resources already allocated". For example, the annual state subsidy made to the Atomic Energy Corporation for uranium enrichment is roughly equal to the combined grant made to the six statutory councils (US\$238 million in 1992). Abolishing this would effectively double the resources available for science and technology development.

The ANC intends to emphasize research fields with higher market potential, such as micro-electronics, information technology, biotechnology and new materials. But it also pledges to "retain a basis of fundamental research which is internationally recognized and relevant to the long-term needs of the country". It also wants to foster cooperation with other southern African countries in science and technology.

Another stipulation of the policy is the creation of affirmative action programmes to increase the numbers of scientists and engineers of all races, both men and women. In 1988,82 per cent of scientists and 96 per cent of engineers in South Africa were white, a consequence of an education system that produces one mathematics and science graduate for every 10,000 black school entrants. Roughly two-thirds of the science graduates are male, a proportion that rises to 98 per cent for engineering graduates.

Among its other proposals, the ANC policy recommends an independent Office of Technology Assessment to monitor technological progress and suggests the establishment of either a Ministry of Research and Technology functioning at cabinet level or a powerful interdepartmental committee. The latter option would not present any significant departure from the present system, in which funds are allocated by a cabinet committee advised by the Scientific Advisory Council.

Commenting on the document, Khotso Mokhale, recently appointed vice president responsible for programmes at the Foundation for Research Development, said that he felt encouraged by "the fact that the ANC has made S\&T such a high priority within their policy debate".

Michael Cherry

\section{NSF opens up long-range plan to public comments}

Washington. Caught off-guard by a directive from Congress to do more for US industry, the National Science Foundation (NSF) has decided to hold a series of public meetings to find out what scientists think. Last week, at a meeting of its National Science Board, NSF announced the creation of a 15person Commission on the Future of the National Science Foundation that will spend three months on such issues as whether it is "appropriate" for NSF to broaden its mandate beyond basic research to support technology and stronger links with industry.

Although the issue of NSF's role in supporting industry has been on the table for months as NSF prepared its strategic plan, language in the Senate version of the bill that sets the agency's budget for 1993 (passed on 3 August) has forced the agency to confront the issue. The Senate instructed NSF to take a "more activist role" in transferring technology from US universities to industry, listing half-a-dozen ways in which it should do this and requiring NSF to revise its strategic planning accordingly.

Walter Massey, the NSF director, says that he is "very disappointed" with the Sen- ate appropriations bill - which, besides providing detailed instructions on how NSF should spend its money, would give the agency barely enough to cover the cost of inflation. He said he has requested a meeting with Senator Barbara Mikulski (Democrat, Maryland), the chairwoman of the appropriations committee that oversees NSF's funding, to discuss his concerns. (The bill must be reconciled with a different version passed last month by the House of Representatives that scarcely mentions industry.)

Massey was vague, however, on just how the Senate language - and the new commission - would affect the agency's planning. Although the commission is intended to get input on the industrial research question from researchers and others outside the agency and its usual advisory bodies, it is not clear how those comments will shape the final strategic plan. Unlike the nearly finished plan of the National Institutes of Health (NIH), the NSF plan may not even emerge as a single document, Massey says. And despite the obvious similarities between NSF's planned open hearings and the five "town meetings" that NIH has held around the country over the past year, Massey said that he was not influenced by the lessons that NIH learned in its own tumultuous planning process.

Instead, Massey said, the decision to turn to the scientific community at large reflects the magnitude of the change now foreseen for the agency. As well as increasing its support for industrial research, NSF is being asked to improve university buildings, undergraduate and pre-college education and US economic competitiveness. Given the degree to which such new responsibilities depart from NSF's traditional role of funding little else besides academic basic research, "we felt we needed a reality check" from the community at large, said James Duderstadt, president of the University of Michigan and chairman of the National Science Board, which endorsed the commission. The commission's members - who will come from universities, industry and other sectors - have not yet been named, but the panel is expected to hold at least three public hearings before it reports back at the end of the year.

Christopher Anderson 